\title{
Measuring the Impact of Social Media Advertising Content on Consumers' Purchasing Intention towards Health and Beauty Products Online ${ }^{1}$
}

\author{
Nourhan A. El-zoghby ${ }^{2}$
}

\author{
Dr. Ahmed M. El-Samadicy3
}

Dr. Eman M. Negm 4

\begin{abstract}
This study seeks to measure the impact of various social media advertising contents on consumers' intentions to purchase health and beauty products online. After reviewing the literature, the researcher found that prior studies considered visual content, user generated content, interactivity content, text-persuasive content, and text-informative content to be significant substance to be placed in social media ads. These substances make consumers attentive to the viewed advertising. Accordingly, the researcher developed a proposed conceptual Model that consist of two phases: phase one focuses on the substance of social media content that creates attentive advertising; phase two focuses on the ad attentiveness impact on consumers purchase intention. Six hypotheses emerged according to the model to be tested through a quantitative research approach. This study is considered conclusive research, with a cross-sectional design and a descriptive purpose. Distribution of online questionnaires is conducted to collect the needed data. Each of the variables is measured using a 5-point Likert scale (the number of the items varied in each scale). A non-probability sampling technique is applied. The studied population in this research is youth and young

${ }^{1}$ Received in 22/1/2021, accepeted in 25/2/2021.

2 Nourhan Adly El-zoghby is currently Researcher at College of Management and Technology, Arab Academy for Science, Technology and Maritime Transport (nourhanadly.elzoghby@gmail.com)

${ }^{3}$ Dr. Ahmed Moussa Elsamadicy is currently Associate Professor at College of Management and Technology, Arab Academy for Science, Technology and Maritime Transport (asamadicy@aast.edu)

${ }^{4}$ Dr. Eman Medhat Negm is currently Associate Professor at College of Management and Technology, Arab Academy for Science, Technology and Maritime Transport (eiman.negm@aast.edu)
\end{abstract}


adults (20 to 35 years old) basically residing in different regions of Egypt as this is the common age of social media audience based on the official statistics made by the Hootsuite in January 2019. Out of 500 self-administrated questionnaires, 412 are returned complete and accurate, yielding a response rate of $82 \%$. Once the needed data is collected, the researcher uses the SPSS (Statistical Package for Social Science) program to carry out several analyses needed to develop empirical insights, such as the reliability analysis, validity analysis, descriptive analysis, frequency analysis, correlation analysis, and multiple regression analysis. Based on the hypotheses testing, the researcher discovered that: in order for health and beauty care products social media advertising to capture consumers' attention, there should be text-persuasive content, interactivity content and text-informative content. Visual content and user generated content is insignificant in capturing consumers attention. This study shows that there is a relationship between consumers' attentiveness with social media advertising and their intentions towards purchasing the promoted health/ beauty products.

Keywords: Advertising - Consumer Behavior - Purchase Intention - Social Media Content Social Media Marketing

\section{1- Introduction}

According to Fior (2020), the global health and beauty products market is expected to grow from USD 493.34 billion in 2018 to USD 756.63 billion by 2026, at a CAGR of $5.81 \%$ during the forecast period 2019 2026. There is high demand for this product category among different consumers as psychologies say that humans are always in constant search for self-improvement (Solomon, 2019). Health, beauty and personal care products are used to enhance the appearance, wellbeing, strength, and condition of the face and body (internally and externally). Sun care, skin care, hair care, deodorants, makeup and color cosmetics, vitamins, and fragrances are some of the products under this category (Binwani et al., 2019). These products have become important to consumers as they develop aware of the vitality of maintaining biological and physical physic and building strong immunity, especially during COVID-19 era (Fior, 2020). Online shopping for health, beauty and personal care products showed rising numbers due to consumers' presence online, especially on social media platforms. In 2020, an estimated of 3.6 billion people are using social media worldwide, a number projected to increase to almost 4.41 billion in 2025 (Clement, 2020; Wiederhold, 2020). 
Researches show that many organizations nowadays decided to advertise and implement various marketing activities online through social media networks due to its popularity among people of all ages around the world (Gaber et al., 2019). Statistics show that $45 \%$ of the world's populations are active users of social media. According to the world statistics (2020), in 2020, the global number of Facebook users is expected to reach 1.69 billion, up from 1.34 million in 2014. Thus, businesses of all fields are recommended to utilize social media networks because it allows brands to access millions of consumers, communicating various information to them about their products and services instantly. That's why social media networks are an attractive place for businesses to advertise, giving them an opportunity to target their consumers easily on daily basis (Gaber et al., 2019). This paper measures the impact of various social media advertising contents on consumers' intentions to purchase health and beauty products online.

Kotler and Armstrong (2018) explained that marketing practices is all about: "engaging customers and managing profitable customer relationships". Businesses currently are using online medium as an efficient marketing communication channel that aids in sales boost (Horbal et al., 2017). A good marketing strategy on social media allow consumers to gather useful information and reviews about certain products; to gain a new social online shopping experience; to develop strong customer-business bond (Liang and Qin, 2018). Consequently, social media marketing practices lead to an increase in customer satisfaction, commitment, and generation of constructive word-ofmouth among people (Hanaysha, 2017).

This study is practically important. Today's market place is cluttered with advertising targeting consumers (even on social media). Many businesses are concerned with understanding the content that should be used to break the clutter and grab consumers' attention and create significant impact (Jolly, 2020). Researches have showed that it is important that marketers seek reliable insights that aid in selecting the right content for creating attractive advertising (Gaber et al., 2019). So in order to guarantee the effectiveness of online advertising, marketers are putting into consideration the roles of different content, such as the 
design, format and characteristics that are able to grab consumers' attention (Lee et al., 2018). Effective online advertising content results in the influences of consumer behavior, creating intentions to purchase the presented product or service (Weber and Schweige, 2017). Therefore, social media advertising content, if done accurately, leads to engagement, comments, virality, retweets, likes, shares, followers, etc. (Gaber et al., 2019). This research aids in emerging insights that is needed by marketers to know what kind of social media content gets that kind of attention by consumers. Despite the broad impact that digital and online marketing has, there is still a lack of knowledge about suitable online promotional techniques and strategies (Hasanat et al., 2020). Therefore, this paper is academically important. The emerged insights add a new aspect, highlighting the most effective advertising content when launching an advertising campaign on social networking sites.

\section{1-1 Research Problem}

Nowadays, due to the popularity of the Internet and its social media networks, advertising on social media is considered significant to the success of businesses today (Gaber et al., 2019). The market though is filled with many companies that communicate to the same target consumers. In the beauty and health industry, there are many competitors that sell similar products (Jan et al., 2019). Therefore, companies need to be aware of how to appeal and grab consumers' attention to their communications (CHUKWU et al., 2019). The process of creating content with the intention of advertising and promoting that content through paid channels needs thorough inquiry (Lee et al., 2018). Prior research claim that it is important to investigate more about how businesses can affect consumer behavior easily through social media, grabbing their attention to online advertising campaigns, using attractive content that can affect and create intentions to purchase such products (Singh and Singh, 2015). Selecting the right content is not an easy approach and needs market research to be successful (Jan et al., 2019).

Theories and models were developed over the years to aid marketers and advertisers in creating various promotion messages to the consumers (Kotler, 2020), including one of the first models (AIDA Model) that emerged during 1898 by E. St. Elmo Lewis. Based on these various 
strategies, in order for advertisers to be influential in communication among consumers' and make them consider the promoted product or service, various content is needed in order to attract consumers and develop their interest and desire for purchase (Kotler and Armstrong, 2018). Advertising act as stimuli, which are supposed to start the purchasing decision (Mawakasege, 2015). Therefore, research explained that advertising is a stimulus-reaction scheme. In order to begin this process, the consumer must notice the advertising. The advertiser must attract the target group's attention. It is needed to know how to attract consumers' attention; which advertising strategies that relate to the content of an advertising message, presentation, or placement is needed (Jolly, 2020). Many prior studies urge the investigation of influential content (Singh and Singh, 2015).

The Cognitive response theory assumes that advertising has the ability to influence the relative importance that individuals attach to various attributes of the product, purchase decision being purely rational (Thorson and Moore, 1996). The primary role of advertising is to provide utilities related to information or search costs. Based on the Affective response theory, it assumes that consumers form their preferences based on pleasure, feelings or emotions arising from exposure to the message. Therefore, the content needs to be engaging and emotionally appealing (Holbrook and O'Shaughnessy, 1984). Given the massive number of advertisements that users can come across, the scarcity of user attention needs to be something all organizations are cognizant of. Therefore, social media advertising content, if done accurately, leads to engagement, virality, retweets, likes, shares, followers, etc. So it is needed to know by marketers what kind of social media content gets that kind of attention by consumers. Therefore, the research problem will be addressed as the following: "What are the significant attractive social media advertising content that impacts consumers' intentions to purchase products (specifically health and beauty products online)?

\section{1-2 Research Objectives}

The main aim of this research is to gain better understanding about how consumers purchase intentions is affected by social media advertising content that they were attentive to. Accordingly, this study intends to 
achieve several research objectives: (R01) to critically review prior studies in order to identify the main content needed in order to create an effective advertising campaign on social media; (RO2) to review the appropriate approach in which the current research can go about in investigating the impact of social media advertising in grabbing attention and influencing consumer intention to purchase the promoted health and beauty products; (RO3) to get empirical data to verify which social media advertising content regarding health and beauty products plays a significant role in impacting Egyptian consumers attention (R04) to verify if consumers' attention towards social media adverting leads to purchase intention

\section{1-3 Research Importance}

This study is considered academically and practically important. The following sections discusses the main research importance for measuring the impact of social media advertising content on consumers intentions to purchase health and beauty products online.

\section{1-3-1 Academic Importance}

Scholars have strongly indicated that the process of creating advertising content through paid channels needs thorough inquiry (Lee et al., 2018). Prior digital marketing research claim that it is important to investigate more about how businesses can create effective and inspiring messages to attract consumer attention online, using various significant content that can affect and create intentions to purchase such products (Singh and Singh, 2015). Selecting the right content to be applied on digital marketing can vary among content used in traditional marketing techniques. Therefore, marketing research is needed to best asses the right digital advertising content (Jan et al., 2019). Furthermore, research have claimed that digital marketing comes in many forms, so content used in one form of digital marketing does not necessarily guarantee the success of adverting on social media. Accordingly, prior studies encourage supplementary research on advertising content related to different forms of digital advertising (Minculete and Olar, 2018).

The existing academic research tend to focus on the executional factors that drive digital engagement, not specifically social media network 
advertising in precise (Ashley and Tuten, 2015; Mawakasege, 2015). Other studies have focused on the significance of the context (the platform), not the content, of advertising, explaining that this is a key determinant of its online advertising effectiveness (Lee et al., 2018). Other studies focused on the impact of advertising generally on consumers' behavior (CHUKWU et al., 2019). Accordingly, there is a gap in literature. Literature compels to know more about the insufficient empirical evidence regarding different advertising content and its power to create attention that consequently affect the consumers purchase intentions online (Simons and Jones, 2017; Jan et al., 2019). Thus, this research aids to make relevant contribution and add empirical evidence to support the significant advertising content to be used on social media.

\section{1-3-2 Practical Importance}

A significant number of people are nowadays aware of the importance of self-image as psychologies proved that humans are always in constant search of self-improvement (Solomon, 2019). Consequently, there is a high demand for health and beauty care products. These products are used to enhance the appearance of face and body (internally and externally) including skincare, hair case, deodorants, make up and cosmetics, vitamins, fragrances....etc. That's' why it's important to launch powerful advertising campaigns that are able to shape people's perceptions towards the information gained through these advertisements and by understanding these psychological cognitive aspects marketers are able to attract more consumers (jackstiene, 2008).

Moreover, health and beauty products industry is in continuous growth as shown in figure 1.1, which consequently directs marketers to promote this category using special techniques (Fatima and Lodhi, 2015) that are able to develop the consumers' emotional reactions (Jan et al., 2019) which as a result leads to a behavioral change. 
The global beauty-industry market has been consistently resilient.

Global beauty-industry retail sales, $\$$ billion

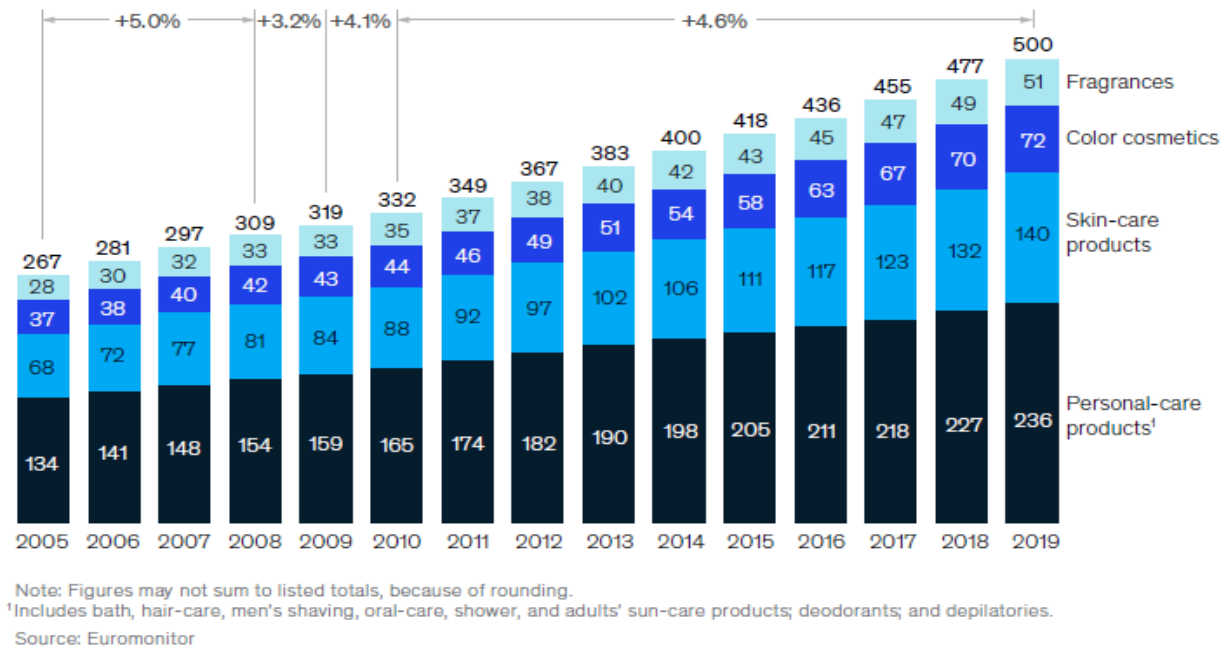

Figure 1.1 The global beauty-industry market (Gerstell et al., 2020)

Due to the corona pandemic disease that has spread all over the world recently, research showed that non-traditional media has become a very popular and frequently used method of advertising especially online through social networking websites. This has made shopping online spread among consumers' worldwide and has become a common method of purchasing products in order to maintain social distancing and isolation (Weiderhold, 2020).

Since social media has been increasing in popularity among people of all ages around the world, many companies decided to advertise through it, as the social media users are in continuous annual growth (Gaber et al., 2019). Social media advertising allows businesses better understand their targeted consumers' behavior, needs, actions, expectations, intentions and engage them with their ads (Jolly, 2020) and increase their fan base too.

The Internet- and online-based social media have changed consumer consumption habits by providing consumers with new ways of looking for, assessing, choosing, and buying goods and services (Harfoushi et al., 2013) (Belch and Belch, 2009) (Goldfarb,2014) (Purusothoman and Rajalakshmi, 2017). These new advanced technology influence how marketers operate and affect marketing practices (Galvan, 2016) 
(Horbal et al., 2017). Various research studies are developing evidence to support the positive implications of using social media in marketing strategies, such as branding, market research, customer relationship management, advertising, and promotion, etc. (Akar and Topcu, 2011)

Consequently, this enables them to use the most convenient methods of implementing an effective marketing strategy based on a marketing analysis that's allows business owners build their future vision focusing on digital marketing (Hanaysha, 2017) and concentrating on new advertising techniques when creating advertisements such as the contents, design, placement and distribution that are able to grab the consumers attention in order to achieve the organizations objectives and on the other hand obtain customers' satisfaction (Lee et al., 2018). Thus, this study seeks to develop insights that will allow businesses to understand the most attractive convenient ways of implementing an effective advertising strategy based on a good marketing analysis.

The right advertising content in advertisements have the ability to influence consumers' behavior, creating intentions to purchase the advertised product. Thus, this study focuses on the social media advertising content that are able to impact the consumers' purchasing intentions including the visual content, user-generated content, interactivity content, text-informative content and text-persuasive content.

Prior research have explained why it is important for businesses to use social media adverting in the market today, making understanding effective advertising content needed (Kaplan \& Haenlein, 2010; Henderson \& Bowley, 2010; Ohajonu \& Mathews, 2015; Singh and Singh, 2015; Mishra and Mahalik, 2017; Hanasysha, 2017; Horbal et al., 2017; Lee et al, 2018; Gaber et al., 2019; Jolly, 2020).

\section{2- Literature Review}

Research has shown that many companies are deciding to advertise online through social media. Social media has been increasing in popularity among people of all ages around the globe (Gaber et al., 2019). Social media advertising is considered a practice that involves the usage of paid advertisements on social networking sites, like Facebook, 
Twitter, YouTube blogs and other different social media different platforms. These networking sites are considered web-based applications and interactive platforms that are able to facilitate the creation, discussion, modification and exchange of the content that is generated by the users themselves (Hasanat et al., 2020). However, social networking sites shifted the idea of consuming Internet services to becoming more interactive and collaborative by creating more opportunities of increasing the interactivity between businesses and the public (Gaber et al., 2019). That's why online advertising through social media is considered one of the best common methods of online marketing nowadays (Mishra and Mahalik, 2017).

In order to guarantee online advertising effectiveness, marketers should concentrate on the creation of the advertisement itself putting into consideration the content, design strategy including the format and characteristics that are able to grab consumers' attention (Lee et al., 2018). The right content in an advertisement can influence consumer behavior, creating intentions to purchase the advertised product (Jolly, 2020). Thus, this section discusses the social media advertising content that are able to influence the purchasing intentions of consumers, including the visual content, user-generated content, interactivity content, text-informative content and finally text-persuasive content. This section also reviews prior study supporting that social media advertising that consumers are attentive towards ar influential in developing consumers' online purchase intentions.

\section{2-1 Visual Contents in Advertising}

Engaging consumers using visuals in the ads is considered one of the most attractive successful tools. Research show that humans' perceptions are developed through various visuals they are exposed to (Taylor, 2014). Visuals are significant in grabbing consumers' attention and creating better understanding as it is considered the most thing that is shared between individuals because it is eye-catching and has got a direct impact on their emotions (Solomon, 2019). Research has proven that visual content taps into the visceral psyche of consumers, encouraging them to discover more about the promoted brand. If marketers and a business can generate high-quality visual content, which 
truly resonates with people and promote it on a regular basis, the reputation and awareness and sales of the product and service will increase (Chron, 2017). Moreover, visual content especially when advertising on social media is able to drive consumers to the company's website, which as a result increases the engagement and interactivity (Gretzel, 2016). Current research showed that visual information is more likely to spread faster than the information presented using texts form (Manic, 2015). Hasanat et al. (2020) explained that visual content in advertising can be shared easily between consumers on social media as it catches the eyes of consumers, allowing them to give their attention to the communicated message. Based on these findings, the current research hypothesized that:

H1: There is a significant relationship between social media advertising visual content and consumers' attention towards the advertising

\section{2-2 User-Generated Content in Advertising}

Due to social media platforms, consumers can easily spread word of mouth online that acts as promotional mechanisms for businesses (Hasanat et al., 2020). The user-generated content on social media is a type of advertising content made by the users. It is information posted by the users online that can be viewed by other users (Agarwal, 2020). User-generated content can take the form of messages, texts, images, videos and multimedia data the people share (Qin and Evrin, 2016). User-generated content creates what is called "viral advertising" as consumers pass and spread endorsed and supported messages about a business' product or service (Moens et al., 2014). However, usergenerated content can be a double-edged weapon. There is no control in what consumers can write or share to other audiences as sometimes they become critics instead of posting persuasive commercial content (Mayrhofer et al., 2020). But, if a user-generated content is constructive, it helps businesses to establish a new engagement technique that leads to increasing product web-traffic and the spread of positive word of mouth (Agarwal, 2020). Based on these findings, the current research hypothesized that:

H2: There is a significant relationship between social media advertising user-generated content and consumers' attention towards the advertising. 


\section{2-3 Interactivity Content in Advertising}

Interactivity is considered an essential notion in the advertising industry that is effective in grabbing consumers' attention (Qin and Evrin, 2016). Kim and McMillan (2008) explained that interactivity advertising creates a two-way communication, controlling consumer engagement, involvement, reactions, physical actions and feedback. Lee and leckenby (2000) clarified advertising interactivity as the presentation and promotion of products or services by a mediated means involving mutual action between consumers and producers. Qin and Evrin, (2016) explained that consumers intermingle with companies by posting comments or sending messages, which later on supports marketers and businesses in the evaluations and information gathering about the brand performance. Consumer interactive content (their expression of satisfaction or dissatisfaction towards certain products) helps marketers to better understand consumers' needs, behavior and intentions (Di Pietro and Pantano, 2012). Current research explained that interactivity of content is appealing to consumers because it has the power to develop and create advertising value among consumers, and it becomes entertaining as consumers' partake in information sharing and receiving (Agarwal, 2020). Based on these findings, the current research hypothesized that:

H3: There is a significant relationship between social media advertising interactive content and consumers' attention towards the advertising.

\section{2-4 Text-informative Content in Advertising}

Research have showed that businesses and marketers design advertisements to be a source of information to consumers (Kotler and Armstrong, 2018). These advertising contain attractive clear specific and action-oriented text messages that include either information content or persuasive content or even a combination of both (Chi, 2019). In order to persuade consumers, marketers need to use words that are informative of the benefits of the product as well as trigger emotional feelings towards the promoted product (Agarwal, 2020). Research show that advertising content should provide full presentation of all the available options in the promoted product or service that interest consumers; and allow them to conclude the product or service is the solution to their 
needs (Lee et al., 2018). Text informative content in advertising contains information about the prices availability and features of the product. Information type of message enlightens consumers about the offers, deals, and discounts about the advertised product (Chi, 2019). This is why previous studies were able to prove that the combination of both personal and informative content in the advertisement is considered the most effective key of engaging more consumers (Lee et al., 2018). Based on these findings, the current research hypothesized that:

H4: There is a significant relationship between social media advertising text informative content and consumers'attention towards the advertising.

\section{2-5 Text-persuasive Content in Advertising}

Research indicated that due to the clutter of advertising that consumers face on a daily bases; marketers need to make sure that advertising is catchy to the consumer (Solomon, 2019). Accordingly, research clarified that it is significant that marketers in advertising use powerful words, explaining the most important conclusions about the product in order to attract eyes on the advertisements (Jolly, 2020). Thus, textspersuasiveness can aid marketers to make sure that advertisement actually grabs and keeps consumers attention (LaMarco, 2018). Textpersuasive ads contain words and content that is designed to elicit a desired action, usually purchasing a product (Chi, 2019). Persuasive content in advertising are aimed to convince consumers to buy the promoted product or service (Lee et al., 2018). Based on research, if marketers decide to advertise a product, this technique is considered powerful in attracting consumers (Agarwal, 2020). Based on these findings, the current research hypothesized that:

H5: There is a significant relationship between social media advertising text persuasive content and consumers' attention towards the advertising.

\section{2-6 Purchase Intention Caused by Online Advertising}

Consumers nowadays can't escape the interference of social media into their daily lives (Online nation report, 2019). They spend most of their time online. It became a source of information and entertainment, which makes the viewer's always exposed to a repetitive pattern of advertisements daily, aiming to deliver certain images with certain 
messages to grab the attention of consumers (Kotler, 2020). According to Hasanat et al. (2020), as consumers spend frequent time online, online advertising become a trigger to encourage consumers to shop online. Digital marketing has encouraged online shopping (Kotler, 2020). Shopping online became easier like never before as the internet is considered now a significant marketing channel supporting two-way communication, providing a healthy interactive shopping channel at any time and at any place (Sunderaraj, 2018). Social media marketing has proved to provide businesses an easy approach to reach all types of consumers with different ages, genders, social class lifestyles...etc., and influence their behavior easily by exposing them to ads that are able to develop their emotional reactions, especially when advertising health and beauty products (Jan et al., 2019). Advertising is able to shape people's cognition, which is the perception towards the information that a person gains through ads as these conditions can be observed through their senses, attention, memory, perception, etc. By understanding these psychological cognitive aspects, marketers are able to attract more consumers (Simons and Jones, 2017). Based on these findings, the current research hypothesized that:

H6: There is a significant relationship between consumers' attention towards the advertising and purchase intention.

Based on the review of the literature and prior research, the following proposed conceptual Model was developed (Figure 1). The proposed conceptual Model consist of two phases: phase one focuses on the substance of social media content that creates attentive advertising; phase two focuses on the ad attentiveness impact on consumers online purchase intention towards health and beauty products. Six hypotheses emerged according to the model to be tested through a quantitative research approach. 
Social media advertising content

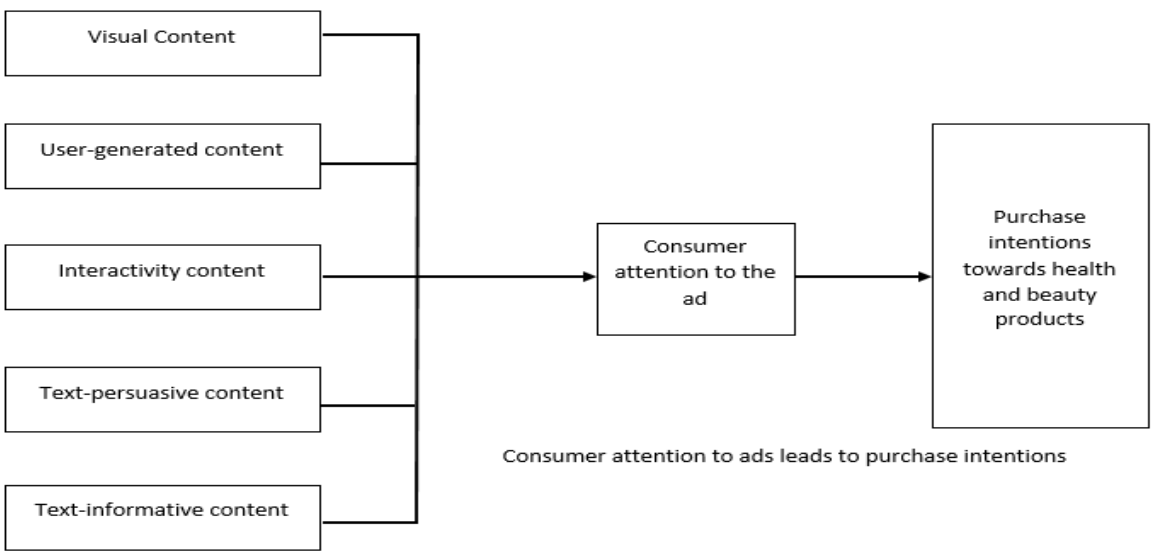

Figure One: The Proposed Research Model

\section{3- Research Methodology}

A quantitative research approach is applied. This study is descriptive research. This research seeks to find objective truths through fact finding approach, generalizing a cross-sectional study of the present state thru September, October, and November 2020.

Data Collection: In this study, the unit of analysis is individual. The researchers, to conduct statistical analysis, gather primary data through administrated questionnaires.

Questionnaire: A structured questionnaire is used, a list of closed ended questions, which the respondents record the answer. Each question is worded exactly as it is to be asked; also the questions are listed in an established sequence. The questionnaire is in the Arabic language. The questionnaire contains an introduction section, which explains the purpose of the research. The next section relates to the consumers' behaviors towards social media and online shopping. The third section relates to social media advertising content (visual content, usergenerated content, interactivity content, text-informative content and text-persuasive content). The scales used to measure these questions are taken from prior studies and adopted to suit the current study context. Each of the variables is measured using a 5-point Likert scale (the number of the items varied in each scale). The next section assesses consumers' attentiveness towards ads and their purchase intention towards beauty and health products online. These questions were also 
taken from prior studies and adopted to suit the current study context. The variables use a 5-point Likert scale. The final section relates to respondents' socio-demographic traits.

Pilot Test: A pilot test is conducted among 50 respondents. The purpose is to assure that the questions in the questionnaire are understandable and the order of questions is logic.

Population and Sampling: This study's population is young Egyptian adult Facebook users. This population is chosen because NapoleonCat statistics (2020) stated that: "there are 42,400,000 Facebook users in Egypt in January 2020, which accounted for $40.2 \%$ of its entire population. People aged 25 to 34 were the largest user group $(14,000,000) "$ (p.1). The sampling technique is non-probability. The distribution took place online, as the researchers posted the link to the questionnaire on facebook groups related to beauty and health products. Sample Size sought is 384 as Krejcie and Morgan (1970) claimed that this sample size is suitable if the population is above 10,000 .

Data Analysis Techniques: To analyze data collected through structured questionnaire, the researchers used statistical software SPSS 22 to conduct various analyses to test they hypotheses and gain insights related to the respondents' behaviors and attitudes towards social media advertising and online purchasing intentions.

\section{4-Data Analysis}

Out of 500 self-administrated questionnaires, 412 are returned complete and accurate, yielding a response rate of $82 \%$. Once the needed data is collected, the researcher uses the SPSS (Statistical Package for Social Science) program to carry out several analyses needed to develop empirical insights, such as the reliability, validity, descriptive, frequency, correlation, and multiple regression analysis.

The respondents in this study came from different socio-demographic backgrounds. Table 1 illustrates the profile of the respondents that participated in the study. 
Table 1: The Respondents Socio-Demographic Backgrounds

\begin{tabular}{|c|c|c|c|c|c|}
\hline Socio-Demographic & FREQ. & $\%$ & Socio-Demographic & FREQ. & $\%$ \\
\hline $\begin{array}{l}\text { Gender } \\
\text { Female } \\
\text { Male }\end{array}$ & $\begin{array}{l}248 \\
164\end{array}$ & $\begin{array}{l}60.2 \\
39.8\end{array}$ & $\begin{array}{l}\text { City of Residence } \\
\text { Cairo } \\
\text { Alexandria } \\
\text { Other }\end{array}$ & $\begin{array}{c}138 \\
223 \\
51 \\
\end{array}$ & $\begin{array}{l}33.5 \\
54.1 \\
12.4 \\
\end{array}$ \\
\hline $\begin{array}{l}\text { Education } \\
\text { High school } \\
\text { College degree } \\
\text { Postgraduate degree } \\
\text { Other }\end{array}$ & $\begin{array}{c}24 \\
203 \\
181 \\
4\end{array}$ & $\begin{array}{c}5.8 \\
49.3 \\
43.9 \\
1.0\end{array}$ & $\begin{array}{l}\text { Age } \\
\text { Under } 20 \\
\text { 20-less than } 35 \\
\text { 35-less than } 50 \\
50 \text {-less than } 65 \\
65 \text { and above } \\
\end{array}$ & $\begin{array}{c}10 \\
254 \\
130 \\
18 \\
0\end{array}$ & $\begin{array}{c}2.4 \\
61.7 \\
31.6 \\
4.4 \\
0\end{array}$ \\
\hline $\begin{array}{l}\text { Marital Status } \\
\text { Single } \\
\text { Married } \\
\text { Divorced/ Separated } \\
\text { Widowed } \\
\end{array}$ & $\begin{array}{c}197 \\
197 \\
15 \\
3 \\
\end{array}$ & $\begin{array}{c}47.8 \\
47.8 \\
3.6 \\
.7 \\
\end{array}$ & $\begin{array}{l}\text { Children } \\
\text { None } \\
\text { One Child } \\
\text { Two Children } \\
\text { More than Two Children }\end{array}$ & $\begin{array}{c}232 \\
56 \\
84 \\
40 \\
\end{array}$ & $\begin{array}{c}56.3 \\
13.6 \\
20.4 \\
9.7 \\
\end{array}$ \\
\hline $\begin{array}{l}\text { Average Monthly Income } \\
\text { Less than } 2,000 \\
2,000 \text {-less than } 5,000 \\
5,000 \text {-less than } 10,000 \\
\text { Over } 10,000\end{array}$ & $\begin{array}{c}24 \\
59 \\
146 \\
183\end{array}$ & $\begin{array}{c}5.8 \\
14.3 \\
35.4 \\
44.4\end{array}$ & $\begin{array}{l}\text { Occupation } \\
\text { Manager/executives } \\
\text { Clerks } \\
\text { Professionals } \\
\text { Academics } \\
\text { Self employed } \\
\text { Laborers } \\
\text { Other } \\
\end{array}$ & $\begin{array}{c}120 \\
12 \\
56 \\
77 \\
75 \\
6 \\
66\end{array}$ & $\begin{array}{c}29.1 \\
2.9 \\
13.6 \\
18.7 \\
18.2 \\
1.5 \\
16.0\end{array}$ \\
\hline
\end{tabular}

The first group of nominal questions relates to the respondents' social media behaviors. The following table (table 2) illustrates the outcomes. According to the analysis, the majority of the respondents go on social media networking sites; the majority of the respondents have Facebook accounts; The majority of the respondents do not have another social media account (only Facebook); the majority of the respondents stay an average of one to two hours a day; the majority of the respondents access social media on their smartphones, but not their computers or tablets. 
Table 2: The Respondents Social Media Behavior

\begin{tabular}{|c|c|c|c|c|c|}
\hline Question & FREQ. & $\%$ & Question & FREQ. & $\%$ \\
\hline $\begin{array}{l}\text { Do you go on social } \\
\text { networking sites? } \\
\text { Yes } \\
\text { No }\end{array}$ & $\begin{array}{c}407 \\
5\end{array}$ & $\begin{array}{c}98.8 \\
1.2\end{array}$ & $\begin{array}{l}\text { Do you have an account } \\
\text { on Facebook? } \\
\text { Yes } \\
\text { No }\end{array}$ & $\begin{array}{c}409 \\
3\end{array}$ & $\begin{array}{c}99.3 \\
.7\end{array}$ \\
\hline $\begin{array}{l}\text { Do you have an account } \\
\text { on other? } \\
\text { Yes } \\
\text { No }\end{array}$ & $\begin{array}{c}86 \\
326\end{array}$ & $\begin{array}{l}20.9 \\
79.1\end{array}$ & $\begin{array}{l}\text { How long are you on } \\
\text { social media per day? } \\
\text { Less than } 1 \text { hour } \\
\text { 1-2 hours } \\
4-5 \text { hours } \\
\text { More than } 6 \text { hours }\end{array}$ & $\begin{array}{c}16 \\
193 \\
186 \\
17\end{array}$ & $\begin{array}{c}3.9 \\
46.8 \\
45.1 \\
4.1\end{array}$ \\
\hline $\begin{array}{l}\text { Do you access Social } \\
\quad \text { Media on your } \\
\text { Computer/Laptop } \\
\text { Yes } \\
\text { No }\end{array}$ & $\begin{array}{l}126 \\
286\end{array}$ & $\begin{array}{l}30.6 \\
69.4\end{array}$ & $\begin{array}{l}\text { Do you access Social } \\
\text { Media on your mobile? } \\
\text { Yes } \\
\text { No }\end{array}$ & $\begin{array}{c}404 \\
8\end{array}$ & $\begin{array}{c}98.1 \\
1.9\end{array}$ \\
\hline $\begin{array}{l}\text { Do you access Social } \\
\text { Media on your Tablets? } \\
\text { Yes } \\
\text { No }\end{array}$ & $\begin{array}{c}50 \\
362\end{array}$ & $\begin{array}{l}12.1 \\
87.9\end{array}$ & $\begin{array}{l}\text { Do you access Social } \\
\text { Media on Other Internet } \\
\text { Devices? } \\
\text { Yes } \\
\text { No }\end{array}$ & $\begin{array}{c}1 \\
411\end{array}$ & $\begin{array}{c}.2 \\
99.8\end{array}$ \\
\hline
\end{tabular}

The next group of nominal questions reflects social media advertising and its usefulness as a source of information. According to the analysis, the majority of the respondents notice social media advertising. They notice the pop-up ads, the sponsored ads that appear while scrolling down the page. They also notice the Facebook fan pages in which the business would upload various videos, pictures, and messages regarding the promoted product or service. The majority of the respondents believe that social media advertising is a good source of information when seeking advice to buy a specific product or consume a specific service. Table 3 illustrates the results of the analyzed questions.

Table 3: Respondents Awareness of Social Media Advertising

\begin{tabular}{|c|c|c|l|c|c|}
\hline Question & FREQ. & $\%$ & \multicolumn{1}{|c|}{ Question } & FREQ. & $\%$ \\
\hline $\begin{array}{c}\text { Do Social media } \\
\text { advertising attract your } \\
\text { attention? }\end{array}$ & & & $\begin{array}{l}\text { Is social media is a source } \\
\text { of information before } \\
\text { purchasing? }\end{array}$ & & \\
Yes & 357 & 86.7 & Yes & 328 & 79.6 \\
No & 55 & 13.3 & No & 84 & 20.4 \\
\hline
\end{tabular}


According to the analysis, the majority of the respondents purchase either monthly or occasionally online; the majority of the respondents buy online beauty and health products, such as makeup, vitamins, calcium, body lotion, hair products, face masks, deodorants, perfumes, and nail polish; the majority of the respondents do not buy over the counter medication nor prescription medication. Table 4 clarifies the analysis.

Table 4: Respondents Online Purchase Behavior on Health and Beauty Products

\begin{tabular}{|c|c|c|c|c|c|}
\hline Question & FREQ. & $\%$ & Question & FREQ. & $\%$ \\
\hline $\begin{array}{l}\quad \text { How often do you } \\
\text { purchase on social media } \\
\quad \text { websites? } \\
\text { Never } \\
\text { Daily } \\
\text { Weekly } \\
\text { Monthly } \\
\text { Annually } \\
\text { Occasionally }\end{array}$ & $\begin{array}{c}27 \\
5 \\
22 \\
104 \\
35 \\
219\end{array}$ & $\begin{array}{c}6.6 \\
1.2 \\
5.3 \\
25.2 \\
8.5 \\
53.2 \\
\end{array}$ & $\begin{array}{l}\text { Do you buy health } \\
\text { and beauty Care } \\
\text { Products online? } \\
\text { Yes } \\
\text { No }\end{array}$ & $\begin{array}{l}213 \\
199\end{array}$ & $\begin{array}{l}51.7 \\
48.3\end{array}$ \\
\hline $\begin{array}{l}\text { Do you buy over the } \\
\text { counter medicine online? } \\
\text { Yes } \\
\text { No }\end{array}$ & $\begin{array}{c}59 \\
353\end{array}$ & $\begin{array}{l}14.3 \\
85.7\end{array}$ & $\begin{array}{l}\quad \begin{array}{c}\text { Do you buy } \\
\text { prescription } \\
\text { medicine online? }\end{array} \\
\text { Yes } \\
\text { No }\end{array}$ & $\begin{array}{l}151 \\
261\end{array}$ & $\begin{array}{l}36.7 \\
63.3\end{array}$ \\
\hline
\end{tabular}

Reliability analysis is defined as the extent to which the measurement of a certain phenomenon provides stable and consistent results (Carmines and Zeller, 1979). Cronbach's alpha is the most common measure of internal consistency (reliability). Validity analysis refers to how well the collected data covers the actual area of investigation (Taherdoost, 2016). If research has high validity, the results are corresponding to the real properties, characteristics and variations in the physical or social world. In this study, the analyses showed that the scales that were used to measure the variables were both reliable and valid. Table 5 illustrates the reliability and validity analysis. 
Table 5: Reliability and Validity Analysis

\begin{tabular}{|l|l|c|c|}
\hline \multicolumn{1}{|c|}{ Variable } & \multicolumn{1}{c|}{ Scale Source } & Cronbach's Alpha & Validity \\
\hline Visual Content & Kujur \& Singh, 2020 & 0.858 & 0.926 \\
\hline User-Generated Content & Alolayyan, 2020 & 0.876 & 0.935 \\
\hline Interactivity Content & Sicilia et al., 2005 & 0.760 & 0.871 \\
\hline $\begin{array}{l}\text { Text-Informative } \\
\text { Content }\end{array}$ & Edwars et al., 2002 & 0.893 & 0.944 \\
\hline Text-Persuasive Content & Chang, 2003 & 0.741 & 0.860 \\
\hline Attention & Bruner et al., 1991 & 0.698 & 0.835 \\
\hline Purchase Intention & $\begin{array}{l}\text { Lepkowska-white, } \\
\text { 2005 }\end{array}$ & 0.929 & 0.963 \\
\hline
\end{tabular}

In this study, the researcher used the multiple regression analysis to test the hypotheses. The multiple regression is an extension of simple linear regression. This analysis allows the researcher to determine the overall fit (variance explained) of the model and the relative contribution of each of the predictors to the total variance explained. In this research, the proposed conceptual Model that consist of two phases: phase one focuses on the substance of social media content that creates attentive advertising; phase two focuses on the ad attentiveness impact on consumers purchase intention. Therefore, the multiple regression analysis was conducted twice. It was conducted first on phase one, and then on phase two.

First, the researcher observed the multiple regression ANOVA to assess if the questionnaires' results are significant or not. The model used in this study was significant, with an ANOVA of 0.000 . The adjusted Rsquared is considered the sum of squares due to regression divided by the sum of total squares. According to the analysis, the adjusted R2 is represents the percentage of variation in the dependent variable explained by variation in the independent variables (Figueredo et al., 2011). When it comes to social media adverting content that creates the consumers' attention, the five independent variables, (1) visual content, (2) user generated content, (3) interactivity content, (4) text informative content and (5) text persuasive content, impacts consumers attention by $44.3 \%$. The remaining $55.7 \%$ are from other variables not taken into consideration in this study. When it comes to consumers' attention grabbed by social media adverting content, it impacts consumers purchase intention by 34.9 . \%. The remaining $60.1 \%$ are from other variables not taken into consideration in this study. 
When testing the hypotheses, the researcher looked at the Sig. Value in the multiple regression. Accordingly, the results show that there is NO relationship between social media advertising visual content and the triggering of consumers attention when it comes to health and beauty products. The relationship between the variables showed the sig value to be more than $0.05(\beta=0.489, p>0.05)$. The results show that there is NO relationship between social media advertising user generated content and the triggering of consumers attention when it comes to health and beauty products. The relationship between the variables showed the sig value to be more than $0.05(\beta=0.281, p>0.05)$. The results show that there is a relationship between social media advertising interactivity content and the triggering of consumers attention when it comes to health and beauty products. The relationship between the variables showed the sig value to be less than $0.05(\beta=0.000, p<0.05)$. The results show that there is a relationship between social media advertising text informative content and the triggering of consumers attention when it comes to health and beauty products. The relationship between the variables showed the sig value to be less than $0.05(\beta=0.000, p<0.05)$. The results show that there is a relationship between social media advertising text persuasive content and the triggering of consumers attention when it comes to health and beauty products. The relationship between the variables showed the sig value to be less than $0.05(\beta=$ $0.000, \mathrm{p}<0.05)$. The results show that there is a relationship between consumers' attention towards social media advertising and the consumers purchase intention when it comes to health and beauty products. The relationship between the variables showed the sig value to be less than $0.05(\beta=0.000, p<0.05)$.

A standardized beta coefficient in the multiple regression illustrates the strength of the effect of each independent variable to the dependent variable. According to this study the variables that have the highest impact on consumers' behavioral intention subsequently are: Text percussive content, Interactivity content, and text informative content. According to the analysis, the variables with the strongest contribution to consumers' attention towards social media advertising are: Text percussive content (Beta $=0.292$ ), Interactivity content (Beta $=0.216$ ), 
and text informative content (Beta $=0.210$ ). Table 6 illustrates the outcome of the Beta Coefficient and the hypothesis testing

Table 6: Hypothesis Testing

\begin{tabular}{|c|c|c|c|}
\hline Hypothesis & $\begin{array}{c}\text { Standardize } \\
\text { d } \\
\text { Coefficients }\end{array}$ & Sig. Value & Conclusion \\
\hline $\begin{array}{l}\text { Hypothesis One: There is a relationship } \\
\text { between social media advertising visual } \\
\text { content and consumers' attention. }\end{array}$ & .034 & .489 & $\begin{array}{l}\text { X Hypothesis not } \\
\text { supported }\end{array}$ \\
\hline $\begin{array}{l}\text { Hypothesis Two: There is a relationship } \\
\text { between social media advertising user } \\
\text { generated content and consumers' } \\
\text { attention. }\end{array}$ & .053 & .281 & $\begin{array}{l}\text { X Hypothesis Not } \\
\text { supported }\end{array}$ \\
\hline $\begin{array}{l}\text { Hypothesis Three: } \text { There is a } \\
\text { relationship between social media } \\
\text { advertising interactivity content and } \\
\text { consumers' attention. }\end{array}$ & $\begin{array}{l}.216 \\
2^{\text {nd }} \text { Strongest } \\
\text { contribution }\end{array}$ & .000 & $\begin{array}{l}\text { Hypothesi } \\
\text { s } \\
\text { supported }\end{array}$ \\
\hline $\begin{array}{l}\text { Hypothesis Four: There is a } \\
\text { relationship between social media } \\
\text { advertising text informative content and } \\
\text { consumers' attention. }\end{array}$ & $\begin{array}{l}.210 \\
3^{\text {rd }} \text { Strongest } \\
\text { contribution }\end{array}$ & .000 & $\begin{array}{l}\text { Hypothesi } \checkmark \\
\text { s } \\
\text { supported }\end{array}$ \\
\hline $\begin{array}{l}\text { Hypothesis Five: There is a relationship } \\
\text { between social media advertising text } \\
\text { persuasive content and consumers' } \\
\text { attention. }\end{array}$ & $\begin{array}{c}.292 \\
\text { Strongest } \\
\text { contribution }\end{array}$ & .000 & $\begin{array}{l}\text { Hypothesi } \checkmark \\
\text { s } \\
\text { supported }\end{array}$ \\
\hline $\begin{array}{l}\text { Hypothesis Six: There is a relationship } \\
\text { between consumers' attention towards } \\
\text { the advertising and purchase intentions } \\
\text { towards health and beauty products. }\end{array}$ & 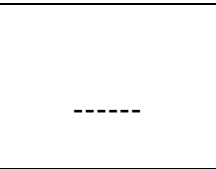 & .000 & $\begin{array}{l}\text { Hypothesi } \\
\text { s } \\
\text { supported }\end{array}$ \\
\hline
\end{tabular}

\section{Discussion and Conclusion}

The aim of this study is to measure the impact of various social media advertising contents on consumers' intentions to purchase health and beauty products online. Accordingly, this study intends to achieve several research objectives: (R01) to critically review prior studies in order to identify the main content needed in order to create an effective advertising campaign on social media; (RO2) to review the appropriate approach in which the current research can go about in investigating the impact of social media advertising in grabbing attention and influencing consumer intention to purchase the promoted health and beauty products; (RO3) to get empirical data to verify which social media advertising content regarding health and beauty products plays a significant role in impacting Egyptian consumers attention (R04) to 
verify if consumers' attention towards social media adverting leads to purchase intention

In order to achieve objective one, identifying the significance of the social media advertising, the researcher conducted the literature review. Based on prior studies, new avenues for online advertising are emerging as new online applications, platforms, and networks increase (Horbal et al., 2017). Online advertising is considered effective because it is costeffective (Mishra and Mahalik, 2017). Online advertising is much more targeted; its value can be tailored through the use of keywords designed to target a specific audience and draw it to specific advertisements (Jolly, 2020). With the Internet and advance technologies, businesses are able to define the consumers they seek. The tracking profiles of consumers have gotten so sophisticated that they can often track an ad impression/click all the way through to an in store purchase. Businesses and marketers can examine response patterns and consumption; this information can then be used to create more effective future advertising campaigns (CHUKWU et al., 2019). Online advertising specially, using social media, has established new connections and created strong bonds and relationships between consumers and marketers. It became a very essential tool of interactivity and engagement as it allows businesses to respond quickly to their consumers' messages, comments, likes and feedback (Liang and Qin, 2018). For social media advertising to be effective, marketers should concentrate on the creation of the advertisement itself putting into consideration the content, design strategy (including the format), and characteristics that are able to grab consumers' attention (Lee et al., 2018). The right content in an advertisement can influence consumer behavior, creating intentions to purchase the advertised product (Jolly, 2020).

Based on prior studies, they found that appealing consumers using visuals in the ads is considered one of the most attractive successful tools. Agarwal, (2020) stated that user-generated content in social media advertising can help marketers to establish a new engagement technique that leads to increasing spread of positive word of mouth. Usergenerated content creates what is called "viral advertising" (Hasanat et al., 2020). Current research explained that interactivity of content is 
appealing to consumers because it has the power to develop and create advertising value among consumers, and it becomes entertaining as consumers' partake in information sharing and receiving (Agarwal, 2020). Other research have concluded that text content, ads that contain words designed to elicit a desired action, usually purchasing a product is significant in appealing to consumers (Chi, 2019). Persuasive content in advertising convince consumers to buy the promoted product or service (Lee et al., 2018). Based on research, these social media content in advertising is considered prevailing in attracting consumers (Agarwal, 2020). Thus, the researchers decided to assess them in the study.

In order to achieve objective two, selecting an appropriate approach to investigate social media advertising content allure and consumer intention to purchase the promoted health and beauty products, the researcher used a quantitative research approach with a descriptive purpose. This research developed empirical evidence that acts as objective truths, generalizing a cross-sectional study of the present state thru September, October, and November 2020. This study's population is young Egyptian adult Facebook users. The sampling technique is nonprobability. The distribution took place online, as the researchers posted the link to the questionnaire on Facebook groups related to beauty and health products. Data was collected from 412 respondents.

Research objective three and four was achieved once the research analysis was conducted. In this objective, the researcher developed empirical data to verify which social media advertising content regarding health and beauty products plays a significant role in impacting Egyptian consumers attention; and verified if consumers' attention towards social media adverting leads to purchase intention. The research results indicated that in order for health and beauty care products social media advertising to capture consumers' attention, there should be textpersuasive content, interactivity content and text-informative content. Visual content and user generated content is insignificant in capturing consumers attention. This study shows that there is a relationship between consumers' attentiveness with social media advertising and their intentions towards purchasing the promoted health/ beauty products. 
With these emerged insights, practitioners can take the research conclusions and create social media advertising that is deemed attractive to young Egyptian Facebook users. This study recommends the usage of social media platforms to help businesses target ideal buyers, which can drive more relevant traffic to the website of the promoted products. Using social media advertising is attractive because it can get a brand in front of people quickly and easily. Furthermore, it gets potential consumers looking at brand even when they aren't thinking about the brand or product (if the ad is designed appealing to the consumers). Therefore, social media advertisements influence consumers in their purchasing decisions. Social media advertising should use powerful words and text in order to capture consumers' attention. All information should be relevant to what you're advertising. The information put in the ad should show prospective consumers how the product can meet their needs or solve their problem. The ad should have useful information, which tells consumers about the product, and accelerate the regular acceptance of the products. This information will lead to interactivity of the consumers, controlling consumer engagement, involvement, reactions, physical actions and feedback. When consumers intermingle with companies by posting comments or sending messages, it then allows other consumers attracted to the ad.

\section{5-1 Research Limitations and Future Direction}

Like any research, this study faced several limitations that future research should take into consideration. This study focused specifically on social media advertising, neglecting other digital marketing techniques. Future studies can apply the proposed conceptual model on other online advertising. In addition, this study focused on Facebook social media, neglecting other social media sites. Future research can apply the model on other social media platforms. This study focused on five types of content in online advertising: (1) visual content, (2) user generated content, (3) interactivity content, (4) text informative content and (5) text persuasive content. Future research can add other advertising content to test. This study tested the model on beauty and health products. Future research can test the model on other product categories, such as FMCG, clothing, home appliances, etc. This study focused on Egyptian context. Future studies can focus on other countries 
in the Middle East or do a comparison study with western countries. Due to time constraints, this study used quantitative research approach (not mixed research); it used a cross sectional time horizon; and it contained a small sample size. Future studies that have a suitable time to conduct research can apply a longitudinal time horizon, increase sample size, and collect qualitative data to gain insights on the justifications of why these media content are attractive. This study was unable to get a sampling frame, so a nonprobability sampling was conducted. Future studies if they are able to gain a sampling frame, then it is recommended to do probability sampling.

\section{5-2 Recommendations}

One of the main goals of this research is to make all the achieved findings become a part of future researches, so based on these conclusions practitioners should consider the consumers behavior and consumption patterns in the Egyptian Society before launching any advertising campaign on social media, it is suggested that in further researchers should be conducted in order to determine whether the consumers behavior differs among different social media platforms or not. Also future studies can examine this model in different countries that rather than Egypt.

To better understand the implications of the results of this research, it is suggested that social media specialists and marketers should concentrate more on the text persuasive and text informative advertising contents putting into consideration the interactivity content too rather than other contents in a way that increases the interactivity and engagement between both parties especially when advertising health and beauty products. This is considered very logical specially when we mention health and beauty care products as people are more attracted either to the ingredients of the product or the offers that are made concerning these types of products, rather than the visuals (photos or videos) of the models in these types of advertising as people believe that all these visuals are fake as designers edit them before posting the ad. Also people believe that the user-generated content that are posted or shared by other social media users depend on their own experience and not all of them tell the truth. 
Moreover, nowadays marketers should take advantage of the world's current situation due to the Corona pandemic disease that has hit the word recently. Marketers should launch attractive powerful messages in their advertising campaigns encouraging people to shop online as it is now safer in order to maintain social distancing. All information should be relevant to what you're advertising. The information put in the ad should show prospective consumers how the product can meet their needs or solve their problem. The ad should have useful information, which tells consumers about the product, and accelerate the regular acceptance of the products. This information will lead to interactivity of the consumers, controlling consumer engagement, involvement, reactions, physical actions and feedback. When consumers intermingle with companies by posting comments or sending messages, it then allows other consumers attracted to the ad.

\section{References}

Social media users in Egypt 2020. [online] Available at: https://napoleoncat.com/stats/facebook-users-inegypt/2020/01.

Agarwal, M. (2020). Importance of User Generated Content as a part of Social Media Marketing that drives Customer's Brand Awareness and Purchase Intentions".

Akar, E. and Topçu, B. (2011). An Examination of the Factors Influencing Consumers' Attitudes Toward Social Media Marketing.

Alolayyan, M.; Mohammed, J.; Quoquab, F. and T., R. (2020). The Effect of User-Generated Content Quality on Brand Engagement: The Mediating Role of Functional And Emotional Values.

Ashley, C. and Tuten, T. (2015). Creative Strategies in Social Media Marketing: An Exploratory Study of Branded Social Content and Consumer Engagement.

Belch, G. and Belch, M. (2009). Advertising and Promotion. An Integrated Marketing Communication Perspective. 3rd ed. [eBook] Available at:

https://www.researchgate.net/publication/46966230 Advertisi 
ng and Promotion An Integrated Marketing Communication Perspective

Binwani, K. and Yin Ho, J. (2019). Effects of Social Media on Cosmetic Brands.

Bruner, G. and Kumar, A. (2002). Similarity analysis of three attitudetoward-the-web site scales.

Chang, c. (2003). Party Bias in Political-Advertising Processing.

Chi, C. (2019). An Introduction to Persuasive Advertising vs. Informative Advertising.

Chukwu, B.; Kanu, E. And Ezeabogu, A. (2019). The Impact Of Advertising On Consumers Buying Behaviour.

Clement, J. (2020). Social media - Statistics \& Facts. [online] Available at: https://www.statista.com/topics/1164/social-networks/.

Content Strategies; Taylor, G. (2014). B2B Content Preferences Survey: Buyers Want Short, Visual, Mobile-Optimized Content. [online] Available at: https://www.demandgenreport.com/industrytopics/content-strategies /2746-b2b-content-preferencessurvey-buyers-want-short-visual-mobile-optimizedcontent.html.

Di Pietro, L. and Pantano, E. (2012). An empirical investigation of social network influence on consumer purchasing decision: The case of Facebook.

Edwards, S. M.; Li, H.; Lee, J.-H. (2002). Forced Exposure and Psychological Reactance: Antecedents and Consequences of the Perceived Intrusiveness of Pop-Up Ads, Journal of Advertising, (31) 3, 83-95

Elzbieta lepkowska-white (2005). Personal Correspondence

Fatima, S. and Lodhi, S. (2015). Impact of Advertisement on Buying Behaviors of the consumers: Study of Cosmetic Industry in Karachi City.

Figueiredo, D.; Rocha, E. and Júnior, S. (2011). What is R2 all about? 
Gaber, H.; Wright, L. and Kooli, K. (2019). Consumer Attitudes towards Instagram Advertisements in Egypt: The Role of the Perceived Advertising Value and Personalization.

GALVAN, S. (2016). Social Media Use in Purchasing Behavior of Professional Hispanic Women

Gerstell, E.; Marchessou, S.; Schmidt, J. and Spagnuolo, E. (2020). How COVID-19 is changing the world of beauty. [Online] mckinsey and company. Available at: https://www.mckinsey.com/industries/consumer-packagedgoods/our-insights/how-covid-19-is-changing-the-world-ofbeauty

Goldfarb, A. (2014). What is Different About Online Advertising?

Gretzel, U. (2021). The Visual Turn in Social Media Marketing.

Hanaysha, J. (2017). An examination of the factors affecting consumer's purchase decision in the Malaysian retail market.

Harfoushi. O.; Alfawwaz. B.; Obeidat. B.; Obiedat. R. and Faris. H., Impact of Internet Advertisement and Its Features on E-Commerce Retail Sales: Evidence from Europe, Journal of Software Engineering and Applications, (6) 11, 564-570, 2013.

Hasanat, M.; Hoque, A.; Hassan, M.; Mou, B. and Hamid, B. (2020). The Lack Of Digital Marketing Skills: Developing A Digital Marketer Model For The Retail Industries.

Henderson, A. and Bowley, R. (2010). Authentic Dialogue? The Role of "Friendship" in a Social Media Recruitment Campaign.

Horbal, N.; Khrushch, M. and Orlykova, B. (2017). Internet advertising: the specifics, tendencies of development and impact on sales.

Jakštienè, S.; Susniene, D. and Valdas, N. (2008). The Psychological Impact of Advertising on the Customer Behavior.

Jan, M.; Haque, A.; Abdullah, K.; Anis, Z. and E-Alam, M. (2019). Elements of advertisement and their impact on buying behaviour: A study of skincare products in Malaysia. 
Jolly, W. (2020). The 6 Most Effective Types of Social Media Advertising in 2021. [online] The Big Commerce Blog. Available at: https://www. bigcommerce.com/blog/social-mediaadvertising/\#2-instagram-advertising.

Kaplan, A. and Haenlein, M. (2010). Users of the World, Unite! The Challenges and Opportunities of Social Media.

Kim, J. and McMillan, S. (2008). Evaluation of Internet Advertising Research: A Bibliometric Analysis of Citations from Key Sources.

Kotler, P. and Armstrong, G. (2018). Principles of marketing. Harlow: Pearson.

KOTLER, P. and Armstrong, G. (2020). Principles of Marketing, Global Edtion. 18th ed. [Place of publication not identified]: Pearson Education Limited.

KREJCIE, R. and MORGAN, D. (1970). Determining Sample Size for Research Activities.

Kujur, F. and Singh, S. (2020). Visual Communication and ConsumerBrand Relationship on Social Networking Sites - Uses \& Gratifications Theory Perspective.

LaMarco, N. (2018). What Is Psychological Pricing? [online] Small Business - Chron.com. Available at: https://smallbusiness.chron.com /psychological-pricing11862.html.

Leckenby, J. and Li, H. (2000). Why We Need the Journal of Interactive Advertising.

Lee, D.; Hosanagar, K. and Nair, H. (2018). The Effect of Advertising Content on Consumer Engagement: Evidence from Facebook* .

Liang, L. and Qin, X. (2018). Research on consumers' online shopping decision-making and recommendation of commodity based on social media network.

LLP, F. (2021). Global Beauty and Personal Care Product Market is Expected to Reach USD 756.63 Billion by 2026: Fior Markets. [online] Globe Newswire News Room. Available at: 
https://www.globenewswire. Com /newsrelease/2020/01/24/1974743/0/en/Global-Beauty-andPersonal-Care-Product-Market-is-Expected-to-Reach-USD-75663-Billion-by-2026-Fior-Markets.html.

Manic, M. (2015). Marketing Engagement through Visual Content.

Minculete, G. and Olar, P. (2018). Approaches to the Modern Concept of Digital Marketing.

mishra and mahalik, (2017). (Pdf) Impact of Online-Advertising on Consumers.

Moens, M.; Li, J. and Chua, T. (2021). Mining User Generated Content. 1st ed.

Mwakasege, G. (2015). Influence of Advertising on Consumer Buying Behaviour: Case Study of Forever Living Cosmetics Products.

Ohajionu, U. and Mathews, S. (2015). Advertising on Social Media And Benefits To Brands.

Purusothaman, U. and Rajalakshmi, C.(2017). Types of Online Advertisements and Online Buyers.

Qing, S. and Evrin, (2016). The value of online advertising: exploring the effects of advertisements on consumer perceptions of media vehicle value.

Sicilia, M.; Ruiz, S. and Munuera, J. (2005). Effects of Interactivity in a Web Site: The Moderating Effect of Need for Cognition.

Simons, H. and Jones, J. (2021). Persuasion in Society. 3rd ed. Available at: https://www.routledge.com/Persuasion-in-Society/JonesSimons/p/book/9781138825666.

Singh, M. and Singh, V. (2015). A Perceptual Study of Factors Affecting the Online Advertising. (5), 39-44

Small Business - Chron.com. (2017). Small Business - Chron.com. [online] Available at: https://smallbusiness.chron.com/.

Solomon, M. (2019). Consumer Behavior. 13th ed. Harlow, United Kingdom: Pearson Education Canada. 
Source: Ofcom Adults' Media Literacy Tracker (2018, 2019). Online nation report 2019. [online] Available at: https://www.ofcom.org.uk/data /assets/pdf file/0024/149253/online-nation-summary.pdf.

Sunderaraj, R. (2018). Impact of Advertisement on Buying Behaviour of Consumers In Sivakasi.

Thorson, Esther, Moore, Jeri (1996). Integrated Communication: Synergy of Persuasive Voices, Mahwah, NJ: Lawrence Erlbaum

Weber, P. and Schweiger, W. (2017). Content Effects: Advertising and Marketing.

Wiederhold, B. (2020). Using Social Media to Our Advantage: Alleviating Anxiety during a Pandemic. 


\title{
قياس تأثير محتوى إعلانات وسائل التواصل الإجتماعي على نية المستهلكين الشرائية لمنتجات الصحة والجمال عبر الإنترنت
}

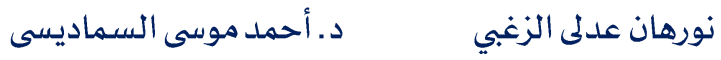

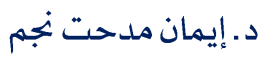 \\ ملخص البحث باللغة العربية
}

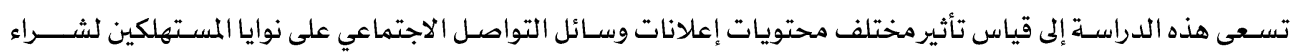

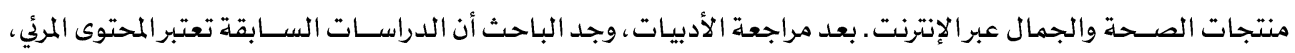

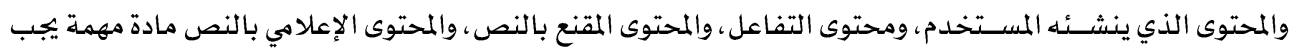

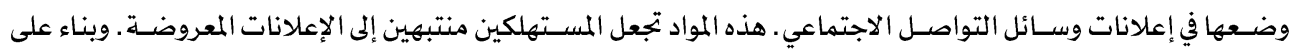

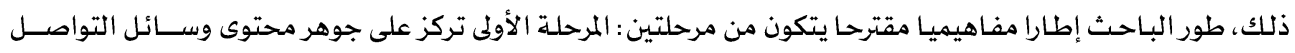

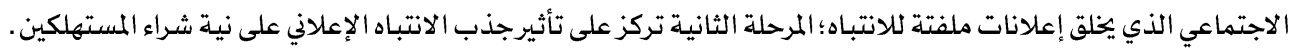

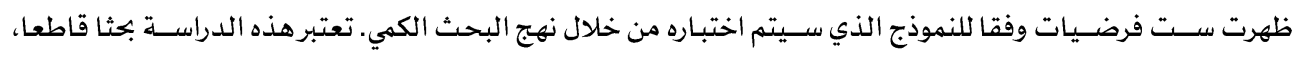

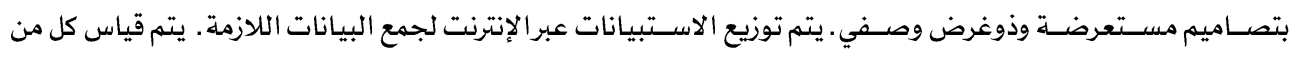
المتغيرات باستخدام مقياس Likert المكون من 5 نقاط (يختلف عدد العناصر في كل مقياس) . يتم تطبيق تقنية أخذ العينات

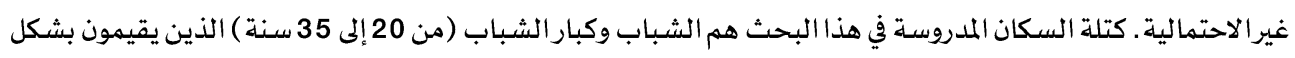

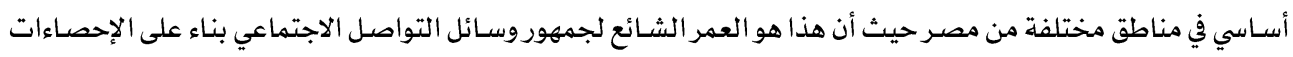

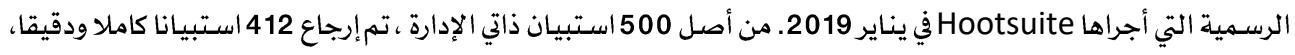

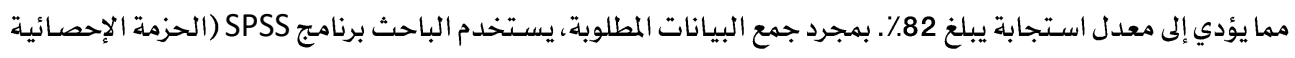

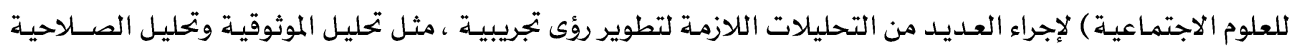

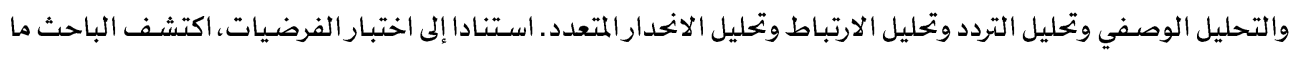

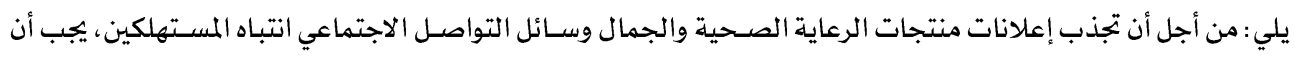

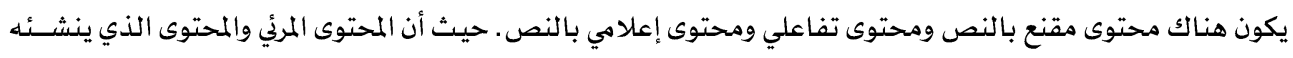

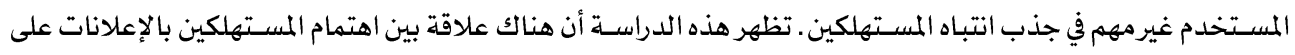

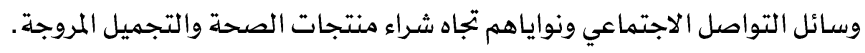

الكلمات الدالة: الإعلان، سـلوك المسـتهلك، نية الشــــراء، محتوى الوسـائط الاجتماعية، والتسـويق عبروسـائل التواصـل

الاجتماع 


\section{Suggested Citation according to APA Style}

El-zoghby, N. A.; El-Samadicy, A. M. and Negm, E. M. (2021). Measuring the Impact of Social Media Advertising Content on Consumers' Purchasing Intention towards Health and Beauty Products Online. Journal of Alexandria University for Administrative Sciences, Faculty of Commerce, Alexandria University 58(2), 159 - 192.

All rights reserved (C) 2021 